SINAI Journal of Applied Sciences (ISSN: 2314-6079) Vol. (8) Is. (2), Aug. 2019

\begin{tabular}{|c|c|c|}
\hline 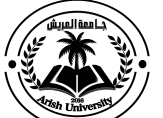 & $\begin{array}{l}\text { SCREENED By SINAI Journal of Applied Sciences } \\
\text { iThenticate }\end{array}$ & $\frac{\text { ARU-EGYPT }}{\text { SJAS }}$ \\
\hline
\end{tabular}

\title{
IMPACT OF CLIMATE CHANGE SCENARIOS ON SOME RAINFED WHEAT CULTIVARS UNDER NORTH SINAI REGION CONDITIONS
}

\author{
Ahmed M. Ali ${ }^{*}$, Eman I. El-Sarag ${ }^{2}$ and M.Y.H. Abdallah ${ }^{3}$ \\ 1. Experts Sector, Minist. Justice, Cairo, Egypt \\ 2. Dept. Plant Prod., Fac. Environ. Agric. Sci., Arish Univ., Egypt. \\ 3. Fac. Des. and Environ. Agric., Matrouh Univ., Egypt.
}

\begin{abstract}
Simulation models are important tools to explore and illustrate dynamics of climatic variables in crop based ecosystem. Two open-field experiments were conducted during 2015/2016 and 2016/2017 seasons at the Experimental Farm, Faculty of Environ. Agric. Sciences, Arish University ( $31^{\circ} 08^{\prime} 04.3^{\prime \prime} \mathrm{N}, 33^{\circ} 49^{\prime} 37.2^{\prime \prime}$ E). This work was aimed to evaluate the performance of four bread wheat (Triticum aestivum L.) cultivars i.e.; Misr-1, Sakha-93, Giza-168 and Gemmeiza-9) in relation to two irrigation pattern i.e. surface supplemental irrigations (12 irrigations) and rainfed under the metrological conditions of North Sinai. Results obtained from experimental field studies were used as indicators to test the performance of DSSAT-CSM (Cropping System Model) Ver. 4.5.1.023. Necessary files were prepared as required. Two different climate scenarios have been implemented in order to study effects of future climate changes on wheat plant growth and yield. Scenarios were done by adding $2^{\circ} \mathrm{C}$ and $4{ }^{\circ} \mathrm{C}$ to maximum and minimum temperatures of the last successful winter season (2016/2017) starting from the best sowing date indicated at conducted field experiments and finishing by the end of growing cycle. The future impacts of climate change on wheat showed that increasing in temperature will reduce length of growing cycle and the time needed to full tillering in addition to the final yield. This subsequently will reduce the amount of grain yield; accelerate time for maturity and harvesting. For $+2{ }^{\circ} \mathrm{C}$ scenario, reduction in grain yield, as predicted by the model, will be reach $9.6 \%$ loses in grain yield for supplementary irrigated Gemmeiza- 9 cultivar and averaged of $18 \%$ among all other cultivars. Scenario of $+4^{\circ} \mathrm{C}$ will reduce supplementary irrigated Gemmeiza-9 grain yield by $16.2 \%$ and within an average of $23.8 \%$ among all other cultivars. The reduction will be more under rainfed irrigation pattern. Generally, Supplementary irrigated Gemmeiza-9 cultivar is recommended treatment to maximized bread wheat grain yield and as an adaption measure to reduce yield variability as affected by increasing of potential temperature scenarios under North Sinai environmental conditions and all similarity regions.
\end{abstract}

Key words: bread wheat cultivars, CERES-Wheat, irrigation pattern, rainfed wheat, Triticum aestivum, crop simulation, climate change scenarios, North Sinai environmental conditions.

\section{INTRODUCTION}

Rise in temperature, particularly in warmer areas, could have a negative effect on wheat productivity in addition to the increasing demand for water requirements. For that reason, more research for adaptation strategies should be explored to reduce the problem of such increasable gap especially under the predicted future climatical changes. There is in general increase the chance of intense precipitation and flooding due to the greater waterholding capacity of a warmer atmosphere (Barnett et al., 2006). Weisheimer and

\footnotetext{
* Corresponding author: Tel.: +201068064047

E-mail address: ah-ma090@yahoo.com
} 
Palmer (2005) examined changes in extreme seasonal temperatures using multimodel multi-scenario ensembles. They showed that by the end of the century, the probability of extreme warm seasons is projected to rise over many areas. This increase in extreme warm seasons arises from the combined effect of a shift in the temperature mean and an increase in the temperature variability. Isolated incidents of extreme high temperatures could seriously damage agricultural crops; a continuous period of extreme high temperature could be deadly. The great challenge for the coming decades will therefore be the task of increasing food production with less water, especially in arid and semi-arid regions (Abouzeid, 1992 and FAO, 2003). Precipitation was projected to decrease by about 163, 163 and $105 \mathrm{~mm}$ during the period of 1990 to 2100 . An increase in temperature may result in a higher evaporative demand of the atmosphere (Yano et al., 2007). Based on the projections of general circulation models (GCMs), the global average temperature is expected to increase between $2^{\circ} \mathrm{C}$ and $4.5^{\circ} \mathrm{C}$ during the current century (IPCC, 2007). The impact of future climate change on crop production has been widely studied by using crop models and climate change scenarios (Hussain and Mudasser, 2007; Challinor and Wheeler, 2008; Tao et al., 2008). Most of the previous researches on the impact of climate change on agricultural sector in Egypt used two scenarios, i.e. $1.5^{\circ} \mathrm{C}$ rise in temperature and $3.6^{\circ} \mathrm{C}$ rise in temperature (GCM results) to predict the impact up the year 2050. These scenarios predicted reduction in wheat grain yield up to $30 \%$ and increase in water needs by about 3\% (Eid et al., 1992; 1993 and 1994) in the year of 2050. Hassanein et al. (2012) pointed out that predicted the rise in the Earth's surface temperature will adversely affect the productivity of many crops in addition to the increasing demand for water requirements. Under Egyptian conditions, wheat productivity will be reduced by $12 \%$ with each $1.5^{\circ} \mathrm{C}$ increase, while this decrease will reach $27 \%$ if the increase in temperature is $3.5^{\circ} \mathrm{C}$. The objectives of this study are to estimate the impact of climate scenarios using DSSATCERES-Wheat Model Ver. 4.5.2 on wheat plant growth and yield under El-ArishNorth Sinai conditions.

\section{MATERIALS AND METHODS}

\section{Field Experiments}

Two open field experiments were conducted at the Experimental Farm, Faculty of Environ. Agric. Sciences, Arish University, North Sinai ( $31^{\circ} 08^{\prime} 04.3^{\prime \prime} \mathrm{N}$, $\left.33^{\circ} 49^{\prime} 37.2^{\prime \prime} \mathrm{E}\right)$, Egypt during two seasons of 2015/2016 and 2016/2017. This work was aimed to evaluate the performance of four bread wheat (Triticum aestivum L.) cultivars i.e., Misr-1, Sakha-93, Giza-168 and Gemmeiza-9 with two irrigation pattern (surface supplementary and rain-fed) under metrological conditions of North Sinai The climatic data of the field experiments, during the growing seasons of wheat plants in 2015/2016 and 2016/2017 were obtained from Central Laboratory for Agriculture Climate (CLAC, Egypt) and presented in Table 1.

Surface supplemental irrigations (12 Irrigations) during wheat growth period was added as recommended for semi arid region. Treatments randomized complete block design (RCBD) in four replicates for each treatment. An area of $359 \mathrm{~m}^{2}$ was ploughed and divided to two blocks for each irrigation pattern (main plots) and wheat cultivars were arranged in the subplots. Row spacing was $15 \mathrm{~cm}$ apart, grains were handly drilled. Fertilization and all other agricultural practices were carried out as recommended for wheat growing under the conditions of North Sinai as a semi-arid land. 
SINAI Journal of Applied Sciences (ISSN: 2314-6079) Vol. (8) Is. (2), Aug. 2019

Table (1): Meteorological data of El-Arish, North Sinai, region during wheat growing seasons of 2015/2016 and 2016/2017.

\begin{tabular}{|c|c|c|c|c|c|c|}
\hline \multirow{2}{*}{$\begin{array}{c}\text { Period } \\
\text { Day (from-to) } \\
\text { /Month/Year } \\
\end{array}$} & \multicolumn{3}{|c|}{ Air Temp. $\left[{ }^{\circ} \mathbf{C}\right]$} & \multirow{2}{*}{$\begin{array}{c}\text { Av. Relative } \\
\text { Humidity } \\
{[\%]} \\
\end{array}$} & \multirow{2}{*}{$\begin{array}{c}\text { Solar } \\
\text { Radiation } \\
{\left[\mathrm{MJ}-\mathrm{hr} / \mathbf{m}^{2} / \mathrm{D}\right]}\end{array}$} & \multirow{2}{*}{$\begin{array}{c}\text { Total } \\
\text { Precipitation } \\
{[\mathbf{m m}]}\end{array}$} \\
\hline & Min. & Max. & Aver. & & & \\
\hline & \multicolumn{5}{|c|}{$2015 / 2016$ season } & \\
\hline 15-30 November 2015 & 18.28 & 23.15 & 20.71 & 66.15 & 10.96 & 8.49 \\
\hline 1-15 December 2015 & 14.63 & 18.65 & 16.64 & 65.43 & 9.45 & 15.83 \\
\hline 16-31 December 2015 & 13.70 & 18.64 & 16.17 & 65.21 & 9.99 & 16.85 \\
\hline 1-15 January 2016 & 12.96 & 17.68 & 15.32 & 69.24 & 8.96 & 14.82 \\
\hline 16-31 January 2016 & 11.35 & 15.09 & 13.22 & 68.71 & 9.92 & 31.28 \\
\hline 1-15 February 2016 & 12.38 & 18.06 & 15.22 & 69.89 & 12.99 & 12.46 \\
\hline 16-29 February 2016 & 14.31 & 20.73 & 17.52 & 70.84 & 16.56 & 13.48 \\
\hline 1-15 March 2016 & 14.51 & 21.42 & 17.97 & 65.46 & 17.31 & 1.41 \\
\hline 16-31 March 2016 & 14.09 & 19.74 & 16.91 & 67.81 & 19.08 & 7.61 \\
\hline 1-15 April 2016 & 16.46 & 23.51 & 19.98 & 68.45 & 21.24 & 9.90 \\
\hline 16-30 April 2016 & 17.94 & 25.69 & 21.81 & 64.99 & 24.18 & 0.00 \\
\hline \multirow[t]{2}{*}{ 1-15 May 2016} & 19.23 & 26.05 & 22.64 & 62.88 & 24.61 & 0.05 \\
\hline & \multicolumn{5}{|c|}{$2016 / 2017$ season } & \\
\hline 15-30 November 2016 & 16.83 & 22.53 & 19.68 & 55.64 & 11.79 & 53.60 \\
\hline 1-15 December 2016 & 14.74 & 18.73 & 16.74 & 68.39 & 9.10 & 55.97 \\
\hline 16-31 December 2016 & 12.45 & 16.36 & 14.40 & 67.74 & 9.38 & 17.15 \\
\hline 1-15 January 2017 & 10.97 & 16.04 & 13.51 & 66.23 & 10.01 & 5.44 \\
\hline 16-31 January 2017 & 12.14 & 16.60 & 14.37 & 70.47 & 10.61 & 10.06 \\
\hline 1-14 February 2017 & 11.70 & 16.72 & 14.21 & 70.57 & 13.25 & 10.41 \\
\hline 15-28 February 2017 & 11.25 & 16.85 & 14.05 & 67.18 & 13.82 & 22.81 \\
\hline 1-15 March 2017 & 13.45 & 19.42 & 16.44 & 71.22 & 17.76 & 3.21 \\
\hline 16-31 March 2017 & 13.90 & 19.35 & 16.62 & 72.22 & 19.06 & 0.23 \\
\hline 1-15 April 2017 & 15.14 & 21.35 & 18.25 & 70.73 & 19.91 & 3.31 \\
\hline 16-30 April 2017 & 16.16 & 23.02 & 19.59 & 66.97 & 24.02 & 0.00 \\
\hline 1-15 Мау 2017 & 18.34 & 25.36 & 21.85 & 68.91 & 25.61 & 0.00 \\
\hline
\end{tabular}

Source: Central Laboratory for Agricultural Climate (CLAC, Egypt). 


\section{Crop Modeling}

Results obtained from experimental field studies and the environmental conditions were used as a data base for calibration and validation of CERES-Wheat through DSSAT-CSM (Cropping System Model) Ver. 4.5.1.023 software to simulate and predict wheat growth and yield. The comparison between actual data (observed) and predicted data were done through CERES-Wheat model under DSSAT interface in three steps, retrieval data (converting data to CERES-Wheat model), and validation data (comparing between predicted and observed data) and run the DSSAT model provides validation of the crop models that allows users to compare simulated outcomes with observed results. Necessary files were prepared as required. Calibration and validation of applying CERES-Wheat model was done through using d-Stat index of agreement between simulated and observed values.

\section{Genetic coefficient}

DSSAT model analyzed the sensitivity of the crop biological responses to changes in the coefficients that relate to phenology. The DSSAT-CERES-Wheat Model was run with weather data and experimental data for the studied four cultivars i.e.; Misr-1, Sakha-93, Giza-168 and Gemmeiza-9 to calculate the genetic coefficient $(\mathrm{P} 1 \mathrm{~V}, \mathrm{P} 1 \mathrm{D}$, P5, G1, G2 and PHINT) for each variety by using sub model GENCALC program, which is part of the DSSAT. The coefficients were prepared as provided by Fayed et al. (2015).

\section{Future Climate Scenarios}

Two different climate scenarios have been implemented in CERES-Wheat model files in order to study effects of future climate changes on wheat plant growth and yield. Scenarios were done by adding $2^{\circ} \mathrm{C}$ and $4^{\circ} \mathrm{C}$ to maximum and minimum temperatures of the last winter successful season $(2016 / 2017)$ starting from the best sowing date indicated at conducted field experiments and finishing by the end of growing cycle.

\section{RESULTS AND DISCUSSION}

It will be necessary to clarify that the two different climatic scenarios which have been implemented using CERES-Wheat model were have added by $\left(2^{\circ} \mathrm{C}\right.$ and $\left.4^{\circ} \mathrm{C}\right)$ to maximum and minimum temperatures of the last successful winter season (2016/2017).

\section{Number of Days From Sowing to Anthesis}

Results presented in Table 2 showed the influence of two climate change scenarios on observed number of days from sowing to anthesis date in 2016/2017 experimental season under North Sinai (El-Arish) environmental conditions.

Compared by recorded number of days to flowering, adding $2^{\circ} \mathrm{C}$ to minimum and maximum temperature will cause a reduction in growing cycle length for all wheat cultivars as affected by irrigation pattern. Reduction in number of days from sowing to anthesis will be about 5 days required period for anthesis of Misr-1 and Gemmeiza-9 cultivars with adding sufficient supplementary irrigation. However, Sakha-93 cultivars will have the longest reduction in days from sowing to anthesis with about 7 days.

Length of growing cycle will be more reduced when the wheat cultivars depend on rain as a main irrigation pattern. In this respect, Fahim et al. (2013) reported that the impact of climate change on the productivity of some major crops in Egypt up to 2050's. It can be concluded that, climate change could decrease national food production from $11 \%$ to $19 \%$. Impacts of climate change on wheat showed that increasing in temperature will reduce length of growing cycle and the time needed to full tillering in addition to the final yield. This subsequently will reduce the amount of grain yield; accelerate time for maturity and harvesting (Hassanein et al., 2012). 
SINAI Journal of Applied Sciences (ISSN: 2314-6079) Vol. (8) Is. (2), Aug. 2019

Table (2): Effects of two climate change scenarios on number of days from sowing to anthesis of four bread wheat cultivars as affected by two irrigation pattern.

\begin{tabular}{|c|c|c|c|c|c|c|}
\hline \multicolumn{3}{|c|}{ Climate change scenario } & \multirow{2}{*}{$+2^{\circ} \mathrm{C}$} & \multirow{2}{*}{$\begin{array}{l}\text { Reduction } \\
\text { [day] }\end{array}$} & \multirow{2}{*}{$+4^{\circ} \mathrm{C}$} & \multirow{2}{*}{$\begin{array}{c}\text { Reduction } \\
\text { [day] }\end{array}$} \\
\hline Cultivar & Irrigation Pattern & Recorded & & & & \\
\hline \multirow{2}{*}{ Misr-1 } & Supplemental Irri. & 95 & 90 & -5 & 86 & -9 \\
\hline & Rainfed & 88 & 83 & -5 & 78 & -10 \\
\hline \multirow{2}{*}{ Sakha-93 } & Supplemental Irri. & 94 & 87 & -7 & 83 & -11 \\
\hline & Rainfed & 89 & 81 & -8 & 76 & -13 \\
\hline \multirow{2}{*}{ Giza-168 } & Supplemental Irri. & 95 & 89 & -6 & 85 & -10 \\
\hline & Rainfed & 88 & 80 & -8 & 76 & -12 \\
\hline \multirow{2}{*}{ Gemmeiza-9 } & Supplemental Irri. & 97 & 92 & -5 & 89 & -8 \\
\hline & Rainfed & 91 & 85 & -6 & 83 & -8 \\
\hline
\end{tabular}

Greater impacts will be observed by adding $4^{\circ} \mathrm{C}$ to minimum and maximum temperature creating more reduction in period required to anthesis with about 8 to 12 days. number of days from sowing to anthesis will be depressed by about 8 days required period for anthesis of Gemmeiza-9 cultivar with both two irrigation pattern. However, Sakha-93 cultivars will have the longest reduction in days from sowing to anthesis with about 11 days with supplementary irrigation pattern and about 13 days under rainfed irrigation pattern. Length of growing cycle will be more reduced when the wheat cultivars depend on rain as a main irrigation pattern by about 10 days for Misr- 1 cultivar and by about 12 days for Giza-168 cultivar.

Comparing the reduction in days to anthesis at both future climate scenarios showed reduction by adding $4^{\circ} \mathrm{C}$ doubled than reduction caused by adding $2^{\circ} \mathrm{C}$ to air temperature of North Sinai region. Simulation ability of the model was similar to what obtained by: El Afandi et al. (2010); Ehteramian et al. (2012); Valizadeh et al. (2014) and Waongo et al. (2015). Whereas, Abdul Haris et al. (2013) who reported that higher temperature during the growing period will decrease the duration of crop growth and wheat yield for future cultivation under climate change simulation in different agro-ecological zones.
Number of days from sowing to physiological maturity date

Results presented in Table 3 show the impact of two climate change scenarios on observed number of days from sowing to physiological maturity date in 2016/2017 effective experimental season under environmental conditions of North Sinai (El-Arish).

Compared by recorded number of days to physiological maturity, $2^{\circ} \mathrm{C}$ increment to minimum and maximum temperature will cause a reduction in growth cycle length for all studied wheat cultivars as affected by irrigation pattern. Reduction will be about 5 days required period for physiological maturity of Misr-1 and Gemmeiza-9 cultivars with adding sufficient supplementary irrigation.

However, Sakha-93 cultivar will have the longest reduction in days from sowing to physiological maturity with about 7 days. Length of growing cycle will be more reduced when the wheat cultivars depend on rain as a main irrigation pattern.

Comparing the reduction in days from sowing to physiological maturity at both future climate scenarios showed reduction by adding $4^{\circ} \mathrm{C}$ doubled than reduction caused by adding $2^{\circ} \mathrm{C}$ to minimum and maximum temperature. Number of days from sowing to physiological maturity will be depressed by about 8-13 days required 
Table (3): Effects of two climate change scenarios on number of days from sowing to physiological maturity of four bread wheat cultivars as affected by two irrigation pattern.

\begin{tabular}{|c|c|c|c|c|c|c|}
\hline \multicolumn{3}{|c|}{ Climate Change Scenario } & \multirow{2}{*}{$+2^{\circ} \mathrm{C}$} & \multirow{2}{*}{$\begin{array}{c}\text { Reduction } \\
\text { [day] }\end{array}$} & \multirow{2}{*}{$+4^{\circ} \mathrm{C}$} & \multirow{2}{*}{$\begin{array}{c}\text { Reduction } \\
\text { [day] }\end{array}$} \\
\hline Cultivar & Irrigation Pattern & Recorded & & & & \\
\hline \multirow{2}{*}{ Misr-1 } & Supplemental Irri. & 144 & 139 & -5 & 135 & -9 \\
\hline & Rainfed & 133 & 128 & -5 & 123 & -10 \\
\hline \multirow{2}{*}{ Sakha-93 } & Supplemental Irri. & 141 & 134 & -7 & 130 & -11 \\
\hline & Rainfed & 131 & 123 & -8 & 118 & -13 \\
\hline \multirow{2}{*}{ Giza-168 } & Supplemental Irri. & 142 & 136 & -6 & 132 & -10 \\
\hline & Rainfed & 132 & 124 & -8 & 120 & -12 \\
\hline \multirow{2}{*}{ Gemmeiza-9 } & Supplemental Irri. & 145 & 140 & -5 & 137 & -8 \\
\hline & Rainfed & 134 & 128 & -6 & 126 & -8 \\
\hline
\end{tabular}

period for an thesis of all studied cultivars. Gemmeiza-9 cultivar with both two irrigation pattern will lose 8 days to reach physiological maturity which be the latest cultivar will reach this stage by 137 days with supplementary irrigation and 126 days under rainfed irrigation. However, Sakha93 cultivars will have the longest reduction in days from sowing to anthesis with about 11 days with supplementary irrigation pattern and about 13 days under rainfed irrigation pattern. Length of growing cycle will be more reduced when the wheat cultivars depend on rain as a main irrigation pattern by about 10 days for Misr- 1 cultivar and by about 12 days for Giza-168 cultivar.

Simulation ability of the model was similar to what obtained by Hassanein and Medany (2007) and Fahim et al. (2013). In this respect, Hassanein et al. (2012) showed that the future impacts of climate change on wheat showed that increasing in temperature will reduce length of growing cycle and the time needed to full tillering in addition to the final yield. Whereas, effects of climate factors on crop growth stages and development inter-related within specific pattern. Meteorological conditions before and after flowering will influence wheat yield and production (Yu et al., 2013).

\section{Grain yield at maturity}

Table 4 shows the impact of two climate change scenarios on observed grain yield in 2016/2017 effective experimental season under environmental conditions of North Sinai (El-Arish).

Compared by recorded grain yield $\mathrm{kg} \mathrm{ha}^{-1}$, the effect of increment in minimum and maximum temperature with the weather conditions of 2016/2017 showed more reduction in grain yield for all studied cultivars at $4{ }^{\circ} \mathrm{C}$ more than $2{ }^{\circ} \mathrm{C}$ as affected by irrigation pattern. Reduction will be about $650 \mathrm{~kg} / \mathrm{ha}$ for Gemmeiza-9 cultivar which will lose $9.6 \%$ of grain yield by adding $2^{\circ} \mathrm{C}$ to the $2016 / 2017$ weather conditions with supplementary irrigation pattern. But the same cultivar will lose $14.2 \%$ of grain yield as affected by rainfed irrigation pattern. While Giza-168 cultivar will lose about $22.5 \%$ of grain yield under 
supplementary irrigation pattern and $26.8 \%$ loses with rainfed irrigation pattern. Comparing the performance of wheat plants showed that grain yield will arrive to 5296 $\mathrm{kg} / \mathrm{ha}$ while it will be reduced to $3928 \mathrm{~kg} / \mathrm{ha}$ as Misr-1 and Sakha-93 cultivars affected by supplementary irrigation pattern. the grain yield of the same cultivar will arrive to $3028 \mathrm{~kg} / \mathrm{ha}$ and $2660 \mathrm{~kg} / \mathrm{ha}$ with rainfed irrigation pattern. According to Waongo et al. (2015) mean yield for the period 20112050 revealed a maximum decrease of $8 \%$ compared to the baseline period.

Greater reduction in grain yield observed by adding $4^{\circ} \mathrm{C}$ to minimum and maximum temperature which caused by reduction in period required to flowering and physiological maturity. This reduction will be more for Giza-168 cultivar than for Misr1; Sakha-93 and Gemmeiza-9 cultivars as affected of both irrigation pattern.

Comparing the reduction in grain yield at both future climate scenarios showed reduction by adding $4^{\circ} \mathrm{C}$ doubled or more than reduction caused by adding $2^{\circ} \mathrm{C}$. As affected by supplementary irrigation pattern, reduction at $4^{\circ} \mathrm{C}$ was more for Misr-1 (1100 $\mathrm{kg} / \mathrm{ha}$ ) but not passed more than $18 \%$ loses of grain yield. While reduction will up to $1030 \mathrm{~kg} / \mathrm{ha}$, Giza-168 cultivar will lose about $30.9 \%$ of grain yield as affected by supplementary irrigation pattern. Also, Gemmeiza-9 and Sakha-93 cultivars will lose about $16.2 \%$ and $22.5 \%$. of grain yield with the same pattern.

Under rainfed irrigation pattern, reduction in grain yield will be more dramatically for all studied cultivars. Gemmeiza-9 cultivar showed resistance in front of future rising in climate temperature with $23.6 \%$ loses in grain yield. In this respect, Maximum wheat yield reduction was obtained under A2 scenario $(57 \%)$ for the third time period (2070-2099) in comparison with the baseline. Nevertheless, B1 scenario showed minimum change in wheat yield for all time periods.
Ehteramian et al. (2012). Also, ElChami and Daccache (2015) found that the direct impacts of climate change on winter wheat, would be a reduction in the rainfed yield (between $-5.4 \%$ and $-32.9 \%$ ). Irrigation could in the future be an adaptation measure for yield increase (10.5\% to 64.3\%). While, El Afandi et al. (2010) revealed high yield reduction in wheat could be expected under climate change conditions, where wheat yield will be reduced by an average of $41 \%$. As well as, Anwar et al. (2007) observed that from present climate to projected low, mid and high global warming scenarios, median wheat yield may decrease by about $29 \%$. Under these scenarios, but with an elevated atmospheric $\mathrm{CO}_{2}$ climate, median wheat yield may decrease by about $25 \%$.

\section{Conclusion}

Simulation of wheat growth and yield using CERES-Wheat model output data model showed that Gemmeiza-9 cultivar recorded the highest observed grain yield in the $2016 / 2017$ season $\left(5928 \mathrm{~kg} \mathrm{ha}^{-1}\right.$ ) as compared to other wheat cultivars Misr-1, Sakha-93 and Giza-168. Reduction will be about $650 \mathrm{~kg} / \mathrm{ha}$ for Gemmeiza-9 cultivar which will lose $9.6 \%$ of grain yield by adding $2{ }^{\circ} \mathrm{C}$ to the $2016 / 2017$ weather conditions with supplementary irrigation pattern. $+4^{\circ} \mathrm{C}$ scenario will obligating Gemmeiza-9 cultivar to lose about $16.2 \%$. of grain yield as affected by supplementary irrigation pattern. while, Under rainfed irrigation pattern, Gemmeiza-9 cultivar showed resistance in front of future rising in climate temperature with $23.6 \%$ loses in grain yield. So, to maximized bread wheat grain yield, it will necessary to recommended that growing Gemmeiza-9 under supplementary irrigated pattern and as an adaption measure to reduce yield variability as affected by increasing of potential temperature scenarios under North Sinai environmental conditions and all similarity regions. 
Table (4): Effects of two climate change scenarios on grain yield $\left(\mathrm{kg} \mathrm{ha}^{-1}\right)$ of four bread wheat cultivars as affected by two irrigation pattern.

\begin{tabular}{|c|c|c|c|c|c|c|c|c|}
\hline \multicolumn{3}{|c|}{ Climate Change Scenario } & \multirow{2}{*}{$+2^{\circ} \mathrm{C}$} & \multirow{2}{*}{$\begin{array}{c}\text { percent } \\
\text { reduction } \\
{[\%]}\end{array}$} & \multirow{2}{*}{$\begin{array}{l}\text { Reduction } \\
{\left[\mathrm{kg} \mathrm{ha}^{-1}\right]}\end{array}$} & \multirow{2}{*}{$+4^{\circ} \mathrm{C}$} & \multirow{2}{*}{$\begin{array}{c}\text { percent } \\
\text { reduction } \\
{[\%]}\end{array}$} & \multirow{2}{*}{$\begin{array}{l}\text { Reduction } \\
{\left[\mathrm{kg} \mathrm{ha}^{-1}\right]}\end{array}$} \\
\hline Cultivar & Irrigation Pattern & Recorded & & & & & & \\
\hline \multirow{2}{*}{ Misr-1 } & Supplemental Irri. & 6096 & 5296 & 13.1 & 800 & 4996 & 18 & 1100 \\
\hline & Rainfed & 3648 & 3028 & 17 & 620 & 2748 & 24.7 & 900 \\
\hline \multirow{2}{*}{ Sakha-93 } & Supplemental Irri. & 4848 & 3948 & 18.6 & 900 & 3758 & 22.5 & 1090 \\
\hline & Rainfed & 3360 & 2660 & 20.8 & 700 & 2440 & 27.4 & 920 \\
\hline \multirow{2}{*}{ Giza-168 } & Supplemental Irri. & 3336 & 2586 & 22.5 & 750 & 2306 & 30.9 & 1030 \\
\hline & Rainfed & 2424 & 1774 & 26.8 & 650 & 1514 & 37.5 & 910 \\
\hline \multirow{2}{*}{ Gemeiza-9 } & Supplemental Irri. & 6768 & 6118 & 9.6 & 650 & 5669 & 16.2 & 1099 \\
\hline & Rainfed & 4776 & 4096 & 14.2 & 680 & 3650 & 23.6 & 1126 \\
\hline
\end{tabular}

\section{REFERENCES}

Abdul Haris, A.; S. Biswas; V. Chhabra; Elanchezhian, R. and Bhatt, B.P. (2013). Impact of climate change on wheat and winter maize over a subhumid climatic environment. Current Sci., 104 (2): 206-214.

Abouzeid, M. (1992). Study on irrigation. Water Res. Centre, Minist. Irrigation and Water Res., Cairo, Egypt.

Anwar, M.R., Leary, G.O.; McNeil, D.; Hossain, H. and Nelson, R. (2007). Climate change impact on rainfed wheat in south-eastern Australia. Field Crops Res., 104: 139-147.

Barnett, D.N.; S.J. Brown; J.M. Murphy; D.M.H. Sexton and M.J. Webb (2006). Quantifying uncertainty in changes in extreme event frequency in response to doubled $\mathrm{CO}_{2}$ using a large ensemble of GCM simulations. Clim. Dyn., 26: 489511.

Challinor, A.J. and Wheeler, T.R. (2008). Crop yield reduction in the tropics under climate change: processes and uncertainties. Agric. and Forest Meteorol., 148: 343-356.

Ehteramian, K.; Normohamadi, G.; Bannyan, M. and Alizadeh, A. (2012). Impacts of climate change scenarios on wheat yield determined by evapotranspiration calculation. Agric., 99 (3): 279-286

Eid, H.M.; Anton, N.A. and Tarrad, A.M. (1994). Comparative study on Egyptian wheat varieties and their response to high temperatures. Ann. Agric. Sci. Moshtohor, 32 (1): 143-154.

Eid, H.M.; Ainer, N.G.; Yousef, K.M.R.; Ibrahim, M.A.M. and Gad El-Rab, G.M. (1992). Climate change crop modeling study on wheat. $5^{\text {th }}$ Egypt. Botan. Conf. Siant Cather. Sinai, 113130.

Eid, H.M.; Ainer, N.G.; M. A. Rady and Risk, W.M. (1993). Impact of Climate change on simulated wheat yield and water needs. $1^{\text {st }}$. Conf. Egypt. Hung. Env. Egypt, 309-312.

El Afandi, G.; Khalil, F.A. and Ouda, S.A. (2010). Using irrigation scheduling to increase water productivity of wheatmaize rotation under climate change conditions. Chilean J. Agric. Res., 70 (3): 474-484.

El-Chami, D. and Daccache, A. (2015). Assessing sustainability of winter wheat production under climate change scenarios in a humid climate. An integrated modelling framework. Agric. Systems. 140:19-25 
Fahim, M.A.; Hassanein, M.K.; Khalil, A.A. and Abou Hadid, A.F. (2013). Climate Change Adaptation Needs for Food Security in Egypt. Nat. and Sci., 11 (12): 68-74.

Fayed T.B.; El-Sarag, E.I.; Hassanein, M.K. and Magdy, A. (2015). Evaluation and prediction of some wheat cultivars productivity in relation to different sowing dates under North Sinai region conditions. Ann. Agric. Sci., 60 (1): 1120.

FAO (2003). Strategy of Agricultural Development in Egypt Up To 2017. MOA. May 2003, Cairo, Egypt.

Hassanein, M.K. and Medany, M.A. (2007). Adapting the CERES-Wheat Model to simulate wheat under current and future climates in Egypt. International Conference on Climatic Changes and Their Impacts on Coastal Zones and River Deltas: Vulnerability, Mitigation, and Adaptation. April 23-25, 2007, Alex., Egypt, 66-81.

Hassanein, M.K.; Elsayed, M. and Khalil, A.A. (2012). Impacts of sowing date, cultivar, irrigation regimes and location on bread wheat production in Egypt under climate change conditions. Nat. and Sci., 10 (12): 141-150.

Hussain, S.S. and Mudasser, M. (2007). Prospects for wheat production under changing climate in mountain areas of Pakistan-an econometric analysis. Agric. Systems, 94: 494-501.

IPCC. Climate Change (2007). The Physical Science Basis/Contribution of
Working Group I to the $4^{\text {th }}$ Assessment Report of the Intergovernmental Panel on Climate Change-Cambridge, UK, New York, USA, 24-57

Tao, F.L.; Hayashi, Y.; Zhang, Z.; Sakamoto, T. and Yokozawa, $M$. (2008). Global warming, rice production, and water use in China: developing a probabilistic assessment. Agric. and Forest Meteorol., 148: 94-110.

Valizadeh, J.; Ziaei, S.M. and Mazloumzadeh, S.M. (2014). Assessing climate change impacts on wheat production (a case study). J. Saudi Soc. Agric. Sci., 13: 107-115

Waongo, M.; Laux, P. and Kunstmann, H. (2015). Adaptation to climate change: The impacts of optimized planting dates on attainable maize yields under rainfed conditions in Burkina Faso. Agric. and Forest Meteorol., 205: 23-39

Weisheimer, A. and Palmer, T.N. (2005). Changing frequency of occurrence of extreme seasonal mean temperatures under global warming. Geophysical Res. Letters, 32: L20721.

Yano, T.; Aydin, M. and Haraguchi, T. (2007). Impact of climate change on irrigation demand and crop growth in a Mediterranean environment of Turkey. Sensors, 7: 2297-2315

Yu, Q.; Li, L.; Luo, Q.; Eamus, D.; Xu, S.; Chen, C.; Wang, E.; Liu, J. and Nielsen, D.C. (2013). Year patterns of climate impact on wheat yields. Int. J. Climatol., Wiley Online Library, DOI: 10.1002/joc.370. 


\section{الملخص العربي \\ تأثير سيناريوهات تغير المناخ علي بعض أصناف القمح تحث ظروف الزراعة المطرية بمنطقة شمال سيناء}

أحمد مجدي علي'، إيمان إسماعيل السراجّ، محمد ياسر حسن عبداللهّ

$$
\text { ا ـ مصلحة الخبر اء، وز ارة العدل، مصر. }
$$

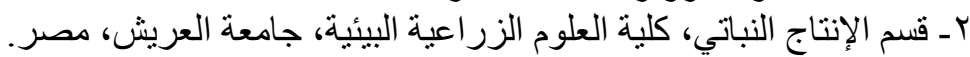

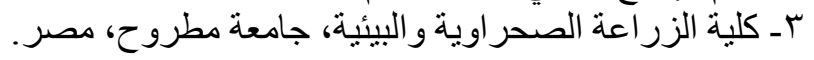

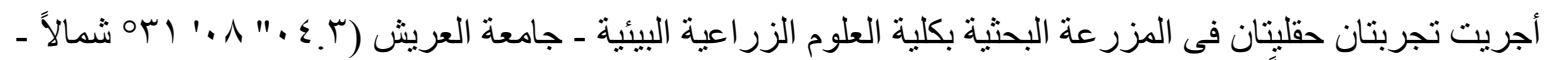

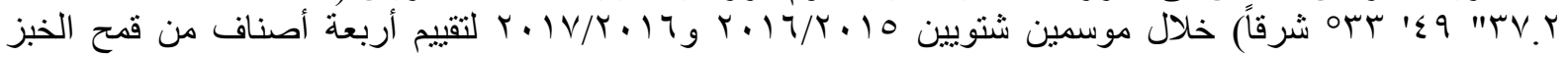

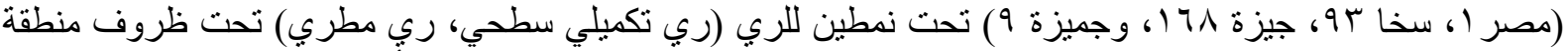

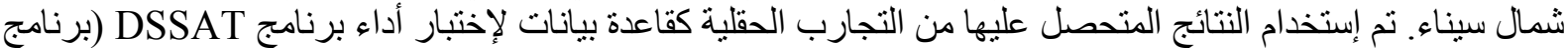

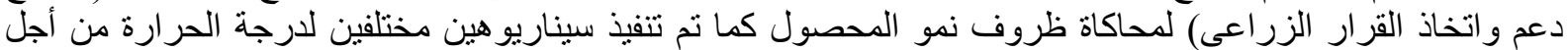

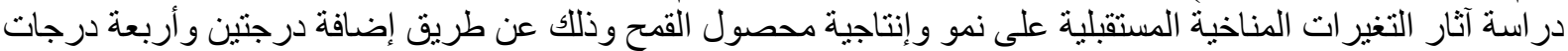

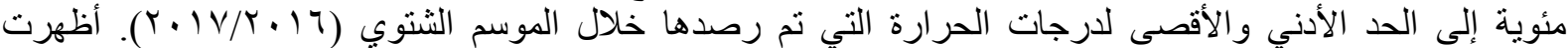

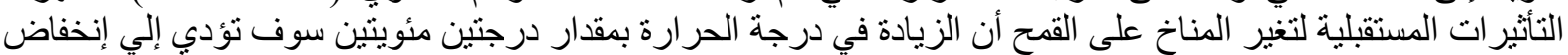

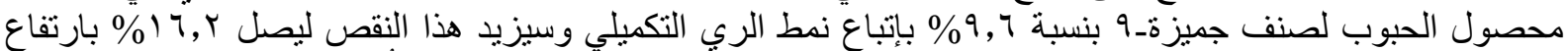



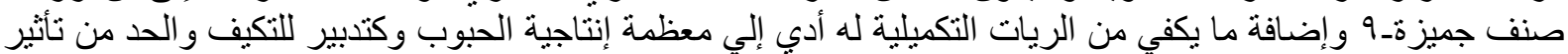

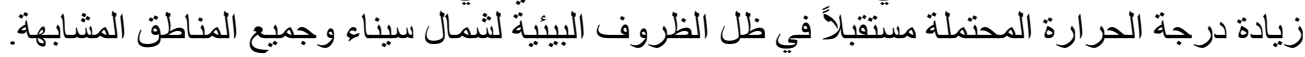
الكلمات الإسترشادية: أصناف قمح الخبز، سينارو هات تغير المناخ، القمح المطري، نماذج محاكاة المحاصيل، الظروف المناخية لثمال سيناء. 